\title{
Effect of hysterectomy on the short life-cycle corpus luteum produced after GnRH-induced ovulation in the anoestrous ewe*
}

\author{
J. A. Southee, M. G. Hunter, A. S. Law and W. Haresign \\ A.F.R.C. Research Group on Hormones and Farm Animal Reproduction, University of Nottingham, \\ Faculty of Agricultural Science, Sutton Bonington, Loughborough, Leics LE12 5RD, U.K.
}

\begin{abstract}
Summary. Anoestrous Romney Marsh ewes were treated with small-dose ( $250 \mathrm{ng})$ multiple injections of GnRH. Ewes in Groups 1 and 3 were hysterectomized 2 weeks before treatment, while those in Groups 2 and 4 were intact controls. Groups 1 and 2 were primed with progesterone $(+\mathrm{P})$ and treated with $2 \mathrm{~h}$ injections of $\mathrm{GnRH}(250 \mathrm{ng})$ for $36 \mathrm{~h}$, while Groups 3 and 4 were not pretreated $(-P)$ but were given $2 \mathrm{~h}$ injections of GnRH ( $250 \mathrm{ng}$ ) for $18 \mathrm{~h}$. Both treatment regimens were terminated with a bolus injection of GnRH $(125 \mu \mathrm{g})$, given to synchronize the timing of the LH surge and subsequent luteal progesterone production.

The plasma progesterone profiles of $5 / 5$ animals in Group $2(+\mathrm{P}$ controls) and $2 / 5$ animals in Group 4 ( - P controls) were indicative of normal luteal function, while the remaining 3/5 animals in Group 4 produced plasma progesterone profiles typical of abnormal luteal function. However, in all the hysterectomized animals (Groups 1 and 3) peripheral plasma progesterone concentrations rose to reach a mean peak value of $1.3 \mathrm{ng} / \mathrm{ml}$ plasma on Day 8 which was maintained in all animals irrespective of progesterone pretreatment. The absence of a fall in progesterone concentrations precluded the identification of any animal in Group 4 showing abnormal luteal function. It was also noted that, after hysterectomy, although the corpus luteum was maintained, it was with reduced secretory capacity.

The prevention of the expected proportion $(70 \%)$ of $-\mathrm{P}$ animals from displaying a decline in plasma progesterone concentration after hysterectomy provides firm evidence that the uterus is involved in the premature regression of the short-cycle corpus luteum.
\end{abstract}

Keywords: abnormal luteal function; hysterectomy; sheep; anoestrus

\section{Introduction}

When ovulation is induced in anoestrous ewes by exogenous GnRH treatment or by the ram effect, the corpus luteum formed in the absence of progesterone priming usually has a short life-span and is capable of producing only a transient rise in plasma progesterone concentration (Knight et al., 1981; Legan et al., 1985; Southee et al., 1988). Progesterone production by these abnormal corpora lutea parallels that of a functionally-normal corpus luteum during the first 4 days after the $\mathrm{LH}$ surge, after which it undergoes premature regressional changes and progesterone production rapidly declines (Southee et al., 1988).

Various factors have been suggested as being the cause of abnormal luteal function in the shortcycle corpus luteum and one of these has been the action on the corpus luteum of a luteolytic or

*Reprint requests to Dr M. G. Hunter. 
antiluteotrophic agent (Lewis et al., 1981; Keisler et al., 1983; Troxel \& Kesler, 1984). The exposure of the induced corpus luteum to high endogenous levels of PGF-2 $\alpha$ has been shown, at least in part, to be the causative factor in the premature regression of the short-cycle corpus luteum in the postpartum cow (Troxel \& Kesler, 1984) and ewe (Lewis et al., 1981) when concentrations of the luteolysin are elevated after parturition. While levels of PGF-2 $\alpha$ remain basal throughout the natural cycle, the normal demise of the corpus luteum at the time of luteal regression is caused by the increased pulsatile secretion of PGF-2 $\alpha$ by the uterus (McCracken et al., 1984). The functional decline exhibited by a short lifecycle corpus luteum produced after GnRH-induced ovulation bears a similarity to the functional and biochemical changes occurring at PGF- $2 \alpha$-induced luteolysis (Hunter et al., 1988).

Therefore, it was the aim of this experiment to determine whether the premature regression of the short-cycle corpus luteum characteristic of GnRH treatment is dependent on the presence of the uterus or is an independent intrinsic feature of the inadequate corpus luteum itself.

\section{Materials and Methods}

Animals and treatment. Anoestrous Romney Marsh ewes were assigned at random during June and July to the four treatment groups according to Table 1: ewes in Groups 1 and 3 were hysterectomized and those in Groups 2 and 4 were sham-operated and acted as intact controls.

Animals were hysterectomized or sham-operated under surgical anaesthesia using sterile precautions 2 weeks before experimental hormone treatment. In the hysterectomized animals ligatures were tied around the uterine arteries and uterine veins and around the utero-cervical junction. The uterus and oviducts were removed leaving the ovarian vasculature intact. The sham-operated control animals were laparotomized as above, and the uterus and ovaries were exteriorized and manipulated before wound closure.

Animals in Groups 1 and 2 were given 2 subcutaneous Silicone implants (Sil-Estrus; Ceva, Paris, France) containing $375 \mathrm{mg}$ progesterone, 7 days before the start of GnRH treatment. Ovulation was induced using the small-dose multiple-injection regimen of Southee et al. (1988), in which animals were injected i.v. via an indwelling jugular vein cannula with $250 \mathrm{ng}$ GnRH (Lutal; Fabewerke Hoechst AG, Frankfurt, West Germany) in 2 ml sterile saline $(9 \mathrm{~g} \mathrm{NaCl} / \mathrm{l})$ at $2 \mathrm{~h}$ intervals. Treatment was terminated by a bolus injection $(125 \mu \mathrm{g})$ of $\mathrm{GnRH}$ after $36 \mathrm{~h}$ (Groups 1 and $2,+\mathrm{P}$ ) or $18 \mathrm{~h}$ (Groups 3 and $4,-\mathrm{P}$ ).

Blood sampling. Blood samples for LH assay were taken immediately before each pulsed injection of GnRH and then at 15-min intervals for $6 \mathrm{~h}$ after the bolus injection of $\mathrm{GnRH}$. Blood samples for progesterone assay were taken at 12-h intervals for the first 10 days after the start of GnRH treatment and then daily for the next 11 days.

Hormone radioimmunoassays. Measurement of progesterone concentration in peripheral plasma was based on the radioimmunoassay method of Haresign et al. (1975) as modified by Hunter et al. (1986). The assay showed negligible cross-reaction with other major steroids and within this study the limit of sensitivity was $0.08 \mathrm{ng} / \mathrm{ml}$, the mean extraction efficiency was $84.5 \pm 2.4 \%$ and the inter- and intra-assay coefficients of variation were 9.8 and $9.1 \%$, respectively. Concentrations of LH in peripheral plasma were determined by the specific double-antibody radioimmunoassay of Foster \& Crighton (1974) as modified by McLeod et al. (1982). The limit of sensitivity of the assay

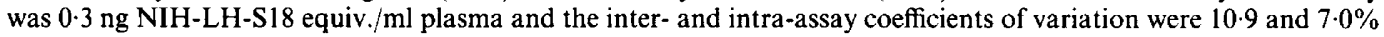
respectively.

Statistical analysis. The results of the hormone assays were analysed in a three-way factorial split-plot analysis of variance. The effects of both pretreatment and treatment on the pattern of LH release and subsequent pattern of progesterone production were further analysed by partitioning the sub-plot factor, blood samples, into linear and quadratic components. Balanced groups of animals were used in the final analysis as shown in Table 1.

The progesterone data from all groups were analysed using (i) the samples collected throughout the whole experiment (Days $0-21$ ) and (ii) the samples collected only over the period in which the intact animals exhibited peak secretion to eliminate the effect of normal luteal regression (Days 6-12).

\section{Results}

The ovulatory response of all the animals treated is shown in Table 1. Subsequent analysis of blood samples for peripheral plasma progesterone concentrations and examination of the ovaries at slaughter after the end of the experiment revealed that a total of $11 / 47$ animals treated, over all experimental groups, had failed to ovulate (see Table 1). Three animals showed evidence that 
ovulation had occurred before GnRH treatment, possibly as a result of surgical intervention, while one animal in Group 2 produced a persistent corpus luteum. The data from all these animals were excluded from the final analysis.

Table 1. Ovulatory response and luteal function of hysterectomized (Hyst.) and intact anoestrous ewes treated for $36 \mathrm{~h}$ or $18 \mathrm{~h}$ with small-dose multiple injections of $\mathrm{GnRH}(250 \mathrm{ng} / 2 \mathrm{~h})$ plus a bolus injection $(125 \mu \mathrm{g})$ with $(+\mathrm{P})$ and without $(-\mathrm{P})$ progesterone pretreatment

\begin{tabular}{|c|c|c|c|c|c|c|c|}
\hline \multirow[b]{2}{*}{ Group } & \multirow[b]{2}{*}{$\begin{array}{l}\text { No. of } \\
\text { animals }\end{array}$} & \multirow[b]{2}{*}{ Surgery } & \multirow[b]{2}{*}{$\begin{array}{l}\text { Progesterone } \\
\text { pretreatment }\end{array}$} & \multirow[b]{2}{*}{$\underset{\text { treatment }}{\mathrm{GnRH}}$} & \multicolumn{3}{|c|}{ No. of animals $(\%)$} \\
\hline & & & & & Ovulated & $\begin{array}{l}\text { With retained } \\
\text { CL }^{*}\end{array}$ & $\begin{array}{l}\text { In final } \\
\text { analysis }\end{array}$ \\
\hline $\begin{array}{l}1 \\
2\end{array}$ & $\begin{array}{r}16 \\
8\end{array}$ & $\begin{array}{l}\text { Hyst. } \\
\text { Intact }\end{array}$ & $\begin{array}{l}+ \\
+\end{array}$ & \} $\begin{array}{c}36 \mathrm{~h}+ \\
\text { bolus }\end{array}$ & $\begin{array}{r}11(69) \\
6(75)\end{array}$ & $\begin{array}{l}11(100) \\
0\end{array}$ & $\begin{array}{r}10 \\
5\end{array}$ \\
\hline $\begin{array}{l}3 \\
4\end{array}$ & $\begin{array}{r}16 \\
8\end{array}$ & $\begin{array}{l}\text { Hyst. } \\
\text { Intact }\end{array}$ & - & $\left\{\begin{array}{l}18 \mathrm{~h}+ \\
\text { bolus }\end{array}\right.$ & $\begin{array}{r}10(62) \\
6(75)\end{array}$ & $\begin{array}{l}10(100) \\
0\end{array}$ & $\begin{array}{r}10 \\
5\end{array}$ \\
\hline
\end{tabular}

*Number of animals exhibiting elevated concentrations of plasma progesterone for at least 21 days.

\section{Plasma LH concentrations}

All animals responded to the bolus injection with an immediate preovulatory LH surge with no significant differences between mean total LH released whether or not the animals ovulated. Similarly, there was no significant difference in the mean peak value of the induced preovulatory LH surge between animals with normal $(38 \pm 6 \mathrm{ng} / \mathrm{ml})$ or abnormal $(33 \pm 8 \mathrm{ng} / \mathrm{ml})$ corpora lutea.

\section{Plasma progesterone profiles}

The $+P$ intact animals (Group 2; $N=5$ ) produced plasma progesterone profiles indicative of normal luteal function (Fig. la), with progesterone concentrations increasing from Day 2 to reach a mean peak level of $2 \mathrm{ng} / \mathrm{ml} 6$ days after the bolus injection, maintained until Day 12, after which progesterone concentration declined.

Abnormal function was defined as a decline in plasma progesterone concentration to below $1 \mathrm{ng} / \mathrm{ml}$ on Day 4 after the end of GnRH treatment (Southee et al., 1988). The mean profile in Fig. 1 (a) includes all 5 animals in the $-P$ control group, 2 of which showed normal luteal function and 3 of which showed abnormal luteal function.

The mean progesterone profiles of the hysterectomized animals in Groups 1 and 3 are shown in Fig. 1(b). Peripheral plasma progesterone concentrations rose in all hysterectomized animals to reach a mean peak value of $1.3 \mathrm{ng} / \mathrm{ml}$ on Day 8 , irrespective of whether they were pretreated with progesterone, and these levels were maintained for the duration of the experiment. Analysis of a blood sample taken from these animals 10 days after the end of the experiment, 31 days after the bolus injection, showed progesterone concentrations of $>1 \mathrm{ng} / \mathrm{ml}$, providing evidence that luteal regression had still not occurred.

\section{Statistical analysis of plasma progesterone profiles}

When all four treatment groups were compared over both time periods, (i) Days 0-21 and (ii) Days 6-12, progesterone pretreatment was shown to have a significant effect on subsequent luteal progesterone because the mean plasma progesterone concentrations in the $+\mathbf{P}$ animals (Groups 1 and 2) were higher than those in the $-\mathrm{P}$ animals (Groups 3 and $4 ; P<0.05$ ). The intact $+\mathrm{P}$ ewes 


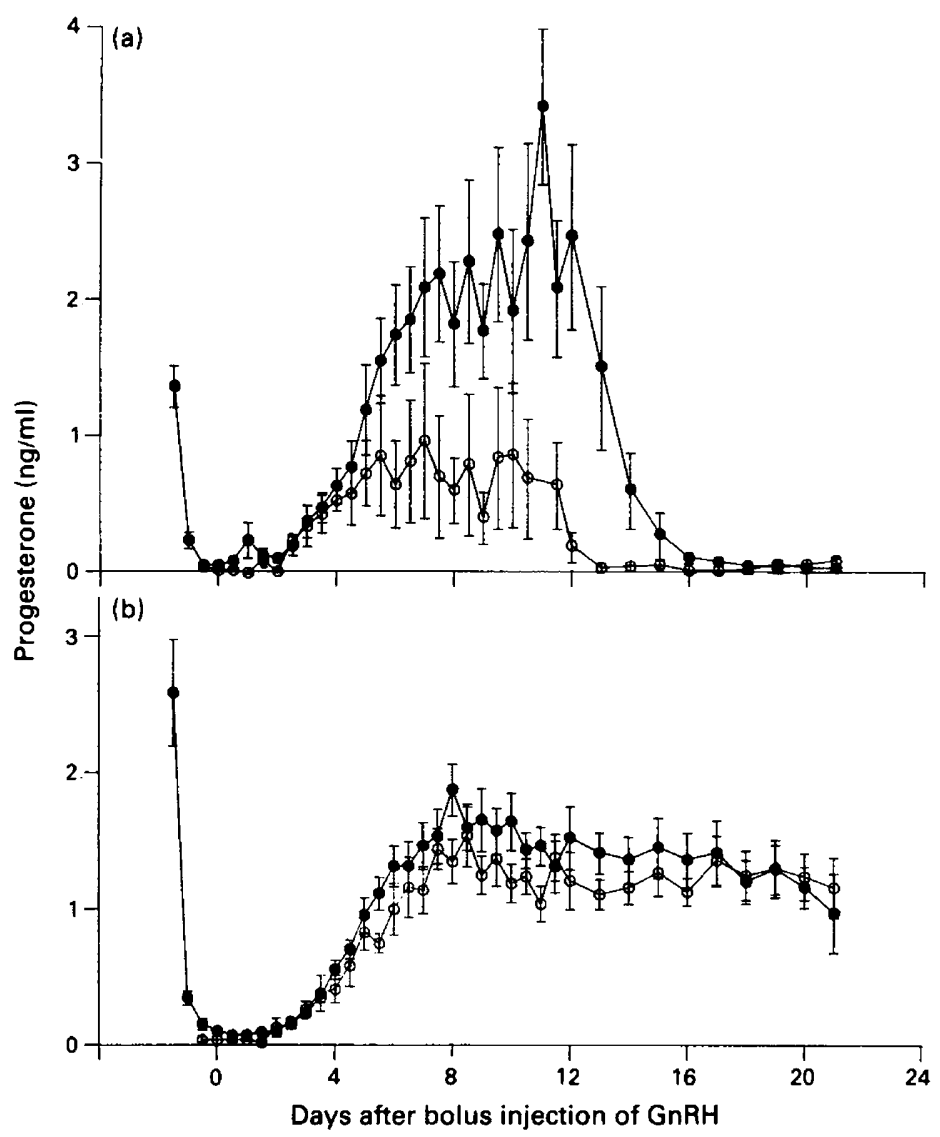

Fig. 1. Plasma progesterone profiles (mean \pm s.e.m.) of anoestrous ewes treated with multiple low-dose injections of GnRH ( $250 \mathrm{ng} / 2 \mathrm{~h}$ ) followed by a bolus injection of GnRH (125 $\mu \mathrm{g})$ : (a) intact ewes from Groups $2(\mathrm{~N}=5)$ and $4(\mathrm{~N}=5)$ and $(\mathrm{b})$ hysterectomized ewes from Groups 1 $(\mathrm{N}=10)$ and $3(\mathrm{~N}=10)$.,$+\mathrm{P}$ ewes treated with $\mathrm{GnRH}$ for $36 \mathrm{~h}+$ bolus $(\mathrm{a}$, Group $2 ; \mathrm{b}$, Group 1); $O,-P$ ewes treated with GnRH for $18 \mathrm{~h}+$ bolus (a, Group 4; b, Group 3).

(Group 2) maintained a higher overall mean plasma progesterone concentration compared to the $-P$ intact animals (Group 4) both during Days $0-21(1.02$ and $0.4 \mathrm{ng} / \mathrm{ml} ; P<0.05)$ and Days 6-12 $(2.09$ and $0.68 \mathrm{ng} / \mathrm{ml} ; P<0.001)$. This effect was modified by hysterectomy and there was no significant difference between the mean plasma progesterone concentrations in the $-\mathbf{P}$ (Group 3 ) and $+\mathbf{P}$ hysterectomized animals (Group 1) in either analysis. The premature regression of the abnormal corpora lutea was prevented and during both periods the animals in the $-\mathrm{P}$ hysterectomized group (Group 3) had a higher mean progesterone concentration (Days 0-21, 0.91 ng/ml; Days 6-12, 1.28 ng/ml) than did those in the $-\mathrm{P}$ control group (Group 4; Days 0-21, 0.4 ng/ml; Days $6-12,0.68 \mathrm{ng} / \mathrm{ml}, P<0.001)$.

However, within the restricted analysis there was a significant treatment $\times$ pretreatment interaction $(P<0.05)$, indicating that hysterectomy had a different effect in the $+P$ and $-P$ animals with regard to luteal progesterone production. While they were not significantly different from each other, all hysterectomized animals (Groups 1 and 2) had lower means (Group 1, 1.54 ng/ml; Group $3,1.28 \mathrm{ng} / \mathrm{ml}$ ) than did the intact $+P$ controls (Group 2, $2.09 \mathrm{ng} / \mathrm{ml}, P<0.001$ ) but higher means than the $-\mathbf{P}$ controls (Group 4, $0.68 \mathrm{ng} / \mathrm{ml}, P<0.001$ ). 


\section{Discussion}

The plasma progesterone profiles of the two control groups (Groups 2 and 4) illustrate that the incidence of normal luteal function in the $+P$ intact animals (Group 2) was $100 \%$ while that in the $-\mathrm{P}$ intact animals (Group 4) was $40 \%$, these values being similar to previous reports (McLeod et al., 1982; Southee et al., 1988). The pattern of plasma progesterone production was, however, dramatically altered by hysterectomy. The failure of the expected proportion of the $-\mathbf{P}$ animals to display a decline in plasma progesterone concentration provides conclusive evidence that the premature regression of the short life-cycle corpus luteum is dependent on the presence of the uterus.

In view of the overwhelming evidence that natural luteolysis at the end of the cycle is caused by the production of PGF-2 $\alpha$ from the uterus (McCracken et al., 1972; Horton \& Poyser, 1976) and that the regressional characteristics of the abnormal corpora lutea are similar to those of corpora lutea subjected to PGF-2 $\alpha$ activity (Hunter et al., 1988), it is likely that PGF-2 $\alpha$ is involved in the regression of the abnormal corpus luteum. The involvement of the uterus and/or PGF-2 $\alpha$ in the premature regression of short life-cycle corpora lutea has previously been suggested in studies conducted in the post-partum cow (Troxel \& Kesler, 1984) and the prepubertal lamb (Keisler et al., 1983).

However, in contrast to the endocrine environment of the post-partum period, which is associated with high circulating concentrations of PGF-2 $\alpha$ (Lewis et al., 1981; Troxel \& Kesler, 1984), it is unlikely that the short-cycle corpus luteum produced in the prepubertal or anoestrous sheep is exposed to abnormally high levels of PGF-2 $\alpha$. It is more likely that this premature, but uterine-dependent, luteolysis may be due to an increased sensitivity of the tissue to the tonic concentrations of uterine luteolysin and/or inadequate luteotrophic protection (Keisler et al., 1983).

This susceptibility to luteolysis occurs around Day 4 after the LH surge, a feature consistent with the attainment of sensitivity of normal cyclic corpora lutea to the administration of exogenous PGF-2 $\alpha$ (Acritopolou \& Haresign, 1980). This feature has been attributed both to the protective effect of $\mathrm{LH}$ receptor saturation during the period immediately after the LH surge (Henderson \& McNatty, 1975) and to the delayed emergence of the large luteal cell population possessing PGF- $2 \alpha$ receptors (Fitz et al., 1982). Day 4 might also be significant as it coincides with the completion of morphological development and the establishment of intercellular channels formed by the microvilli within the corpus luteum (McClellan et al., 1975), and if cellular communication is indeed necessary for the luteolytic action of PGF-2 $\alpha$ (Rodgers et al., 1985) this may explain why it is ineffective before Day 4.

However, the reason for a possible increased sensitivity of the induced abnormal compared to the normal corpus luteum to presumably similar levels of PGF- $2 \alpha$ has yet to be fully determined. One reason for this enhanced susceptibility might be due to an imbalance in the relative number of large cells possessing receptors for PGF-2 $\alpha$ (Manns et al., 1983) or an increase in the receptor affinity (Rao et al., 1979). Day 4 also coincides with the invasion of the luteal structure by the capillary network and the completion of luteal vascularization (McClellan et al., 1975). There is no doubt that vasoconstriction plays a significant role in natural luteal regression (Niswender $e t$ al., 1976; Nett \& Niswender, 1981) and it is possible that inadequate vascularization of the corpus luteum may leave it more vulnerable to the vasoconstrictive effects of PGF- $2 \alpha$ leading to premature regression on Day 4.

The role of oxytocin should also be considered in this uterine-dependent regression occurring on Day 4. Luteal oxytocin is involved in the regression of the normal corpus luteum (Milne, 1963; Flint \& Sheldrick, 1983) and an imbalance in luteal levels of oxytocin or a change in the response of the uterus to basal concentrations of oxytocin might be the cause of the abnormality.

With reference to the final analysis of variance, the significant treatment $\times$ pretreatment interaction $(P<0.05)$ indicates that within the restricted period of Days 6-12 the effect of hysterectomy 
was different in all four treatment groups. This suggests that, while hysterectomy removed the negative effect of the uterus and prevented the premature regression of the abnormal corpus luteum, it did not eliminate all the causes of its abnormality. While the influence of surgical trauma might also be considered, this significant interaction may have occurred because in the absence of the uterus, the corpus luteum never achieved maximum development and retained a limited secretory capacity over its maintained period.

Two factors may therefore be determined from this study; (1) the abnormal GnRH-induced corpus luteum attains susceptibility to the negative effects of the uterus 4 days after the LH surge which was counteracted by hysterectomy, and (2) after removal of the uterus the corpus luteum was maintained but possibly with a limited secretory capacity. Both these characteristics may well be a direct consequence of inadequate follicle development and possible inadequacies within the microvasculature of the preovulatory follicle and the ultimate corpus luteum.

The results of this experiment provide conclusive evidence that while hysterectomy may not result in the full restoration of luteal function in non-primed GnRH-treated anoestrous ewes, it does prevent the premature regression of the abnormal corpus luteum.

We thank the AFRC for financial support; NIH for standard hormone preparations; Hoechst Pharmaceuticals for supplies of GnRH; and Mr T. Parkinson for his surgical skills.

\section{References}

Acritopoulou, S. \& Haresign, W. (1980) Response of ewes to a single injection of an analogue of PGF-2 $\alpha$ given at different stages of the oestrous cycle. $J$. Reprod. Fert. 58, 219-223.

Fitz, T.A., Mayan, M.H., Sawyer, H.R. \& Niswender, G. D. (1982) Characterisation of two steroidogenic cell types in the ovine corpus luteum. Biol. Reprod. 27, $703-711$.

Flint, A.P.F. \& Sheldrick, E.L. (1983) Evidence for a systemic role for oxytocin in luteal regression in sheep. $J$. Reprod. Fert. 67, 215-225.

Foster, J.P. \& Crighton, D.B. (1974) Luteinizing hormone (LH) release after single injections of a synthetic LH-releasing hormone ( $\mathrm{LH}-\mathrm{RH})$ in the ewe at three different reproductive stages and comparison with natural LH release at oestrus. Theriogenology 2, $87-100$.

Haresign, W., Foster, J.P., Haynes, N.B., Crighton, D.B. \& Lamming, G.E. (1975) Progesterone levels following treatment of seasonally anoestrous ewes with synthetic LH-releasing hormone. J. Reprod. Fert. 43, 269-279.

Henderson, K.M. \& McNatty, K.P. (1975) A biochemical hypothesis to explain the mechanism of luteal regression. Prostaglandins 9, 779-797.

Horton, E.W. \& Poyser, N.L. (1976) Uterine luteolytic hormone: a physiological role for prostaglandin $\mathrm{F} 2 \alpha$. Physiol. Rev. 56, 595-651.

Hunter, M.G., Southee, J.A. \& Lamming, G.E. (1988) Function of abnormal corpora lutea in vitro after GnRH-induced ovulation in the anoestrous ewe. $J$. Reprod. Fert. 84, 139-148.

Hunter, M.G., Southee, J.A., McLeod, B.J. \& Haresign, W. (1986) Progesterone pretreatment has a direct effect on GnRH induced preovulatory follicles to determine their ability to develop into normal corpora lutea in anoestrous ewes. $J$. Reprod. Fert. 76, $349-363$.
Keisler, D.H., Inskeep, E.K. \& Dailey, R.A. (1983) First luteal tissue in ewe lambs: influence on subsequent ovarian activity and response to hysterectomy. $J$. Anim. Sci. 57, 150-156.

Knight, T.W., Tervitt, A.R. \& Fairclough, R.J. (1981) Corpus luteum function in ewes stimulated by rams. Theriogenology 15, 183-190.

Legan, S.J., I'Anson, H., Fitzgerald, B.P. \& Akaydin, M.S., Jr (1985) Importance of short luteal phases in the endocrine mechanism controlling initiation of estrous cycles in anoestrous ewes. Endocrinology 117, 1530-1536.

Lewis, G.S., Lishman, A.W., Butcher, R.L., Dailey, R.A. \& Inskeep, E.K. (1981) Factors affecting function of induced corpora lutea in post partum anoestrous ewes. J. Anim. Sci. 52, 1122-1129.

Manns, J.G., Humphrey, W.D., Flood, P.F., Mapletoft, R.J., Rawlings, N. \& Cheng, K. W. (1983) Endocrine profiles and functional characteristics of corpora lutea following onset of post partum ovarian activity in beef cows. Can. J. Anim. Sci. 63, 331-347.

McClellan, M.C., Diekman, M.A., Abel, J.H., Jr \& Niswender, G.D. (1975) Luteinizing hormone, progesterone and the morphological development of normal and superovulated corpora lutea in sheep. Cell Tiss. Res. 164, 291-307.

McCracken, J.A., Carlson, J.C., Glew, M.C., Goding, J.R., Baird, D.T., Green, K. \& Samuelsson, B. (1972) Prostaglandin $\mathrm{F}_{2} \alpha$ identified as a luteolytic hormone in the sheep. Nature, Lond. 238, 129-134.

McCracken, J.A., Schramm, W. \& Okulicz, W.C. (1984) Hormone receptor control of pulsatile secretion of $\mathrm{PGF}_{2} \alpha$ from the ovine uterus during luteolysis and its abrogation in early pregnancy. Anim. Reprod. Sci. 7 , $3 \mathbf{l}-55$.

McLeod, B.J., Haresign, W. \& Lamming, G.E. (1982) The induction of ovulation and luteal function in seasonally anoestrous ewes treated with small-dose 
multiple injections of Gn-RH. J. Reprod. Fert. 65, 215-221.

Milne, J.A. (1963) Effect of oxytocin on the oestrous cycle of the ewe. Aust. vet. J. 39, 51-52.

Nett, T.M. \& Niswender, G.D. (1981) Luteal blood flow and receptors for $\mathrm{LH}$ during $\mathrm{PGF}_{2} \alpha$-induced luteolysis: production of $\mathrm{PGE}_{2}$ and $\mathrm{PGF}_{2}$ during early pregnancy. Acta vet. scand., Suppl. 77, 117-130.

Niswender, G.D., Reimers, T.J., Diekman, M.A. \& Nett, T.M. (1976) Blood flow: a mediator of ovarian function. Biol. Reprod. 14, 64-81.

Rao, Ch.V., Estergreen, V.L., Carmen, F.R., Jr \& Moss, G.E. (1979) Receptors for gonadotrophin and prostaglandin $\mathrm{F}_{2} \alpha$ in bovine corpora lutea of early, mid and late luteal phase. Acta endocr., Copenh. 91, 529-537.
Rodgers, R.J., O'Shea, J.D. \& Findlay, J.K. (1985) Do small and large luteal cells of the sheep interact in the production of progesterone? J. Reprod. Fert. 75, 85-94.

Southee, J.A., Hunter, M.G. \& Haresign, W. (1988) Function of abnormal corpora lutea in vivo after GnRH-induced ovulation in the anoestrous ewe. $J$. Reprod. Fert. 84, 131-137.

Troxel, T.R. \& Kesler, D.J. (1984) Ability of Indomethacin to alter prostaglandin metabolite concentrations and to enhance the function of corpora lutea induced in post partum suckled beef cows. J. Anim. Sci. 59, 177-181.

Received 21 December 1987 